\title{
Soil Matric Potential Based Irrigation Schedule for Brinjal
}

\author{
M. Manikandan* and V. Ravikumar \\ Agricultural Engineering College \& Research Institute (TNAU), \\ Kumulur - 621 712, Tamil Nadu, India \\ *Corresponding author
}

\section{A B S T R A C T}

\section{Keywords}

Soil matric potential,

Tensiometer, Crop coefficient, Crop evapotranspiration

\section{Article Info}

Accepted:

26 July 2020

Available Online:

10 August 2020
The present study aimed to determine irrigation depth and interval based on soil water potential fluctuation monitoring for Brinjal. Field experiment was conducted at Agricultural Engineering College and Research Institute, Kumulur, Tamil Nadu during the two crop growing seasons from 13 November 2018 to 22 March 2019 and 13 April 2019 to 20 August 2019. Brinjal F1 hybrid Dhruva was transplanted at the row spacing of $90 \mathrm{~cm}$ and plant spacing was $45 \mathrm{~cm}$. For drip irrigation system inline laterals were laid at the spacing of $90 \mathrm{~cm}$ with dripper spacing of $45 \mathrm{~cm}$ and dripper discharge of $4 \mathrm{lph}$. To assess the right time of irrigation, soil matric potential was measured by tensiometers installed at the maximum rooting intensity $(10 \mathrm{~cm})$ and rooting depth of crop. The soil matric potential was observed at three times in a day $8 \mathrm{am}, 2 \mathrm{pm}$ and $5 \mathrm{pm}$. Irrigation was given when the soil matric potential reached 15 to $20 \mathrm{kPa}$. Actual ETc was estimated using soil water balance method and reference evapotranspiration ET was used to estimate crop coefficient values for different crop growing stages. The ETo calculator was used to calculate the reference evapotranspiration from the 25 years meteorological date and the 25 years average reference evapotranspiration were taken for this study. From this study irrigation interval was decided based on soil matric potential threshold values, it was found as 1 to 2 days. Computed Kc values at initial, development, mid and end stage of the brinjal for I crop period was $0.57,0.83,1.03,0.84$ and for II crop period was $0.59,0.84,1.02,0.82$. Field test verification of crop water requirement for drip irrigated brinjal by soil water balance method shows that Food \& Agricultural Organization (FAO) method can be used by farmers to irrigate the crops.

\section{Introduction}

Brinjal is one of the most commonly used vegetable in Indian households from the highest consumption point of view. Brinjal (Solenum melongena) is considered native to India and is a widely grown vegetable in Asian countries. India is the second largest producer of Brinjal after China. Total area cultivated and production of brinjal in India was 0.66 million hectare and 12.5 million tonnes respectively. West Bengal is the chief state for production of brinjal followed by Odisha and Gujarat. Among the Indian states Gujarat recorded higher brinjal cultivated area of 0.76 lakh hectare and production of 14.77 lakh tonnes. Uttar-Pradesh registered higher productivity of $34.34 \mathrm{MT} / \mathrm{ha}$ followed by 
Karnataka, Andhra Pradesh and Himachal Pradesh. Tamil Nadu produced 2,45,840 MT of Brinjal from an area of $15,120 \mathrm{Ha}$ with the productivity of 16.26 MT/ha for 2015-16 (Horticultural Statistics at a Glance, 2017). Though the production and consumption of Brinjal in Tamil Nadu and India is increasing linearly, their productivity is limited by several factors, particularly water management.

To manage water, maximize water productivity under the water scarce situations, drip irrigation, a best practice for producing high quality profitable brinjal. Under drip irrigation, crops are irrigated with close interval and little required amount to the crop, face slight soil water stress, but produces higher yield and water saving (Li et al, 2007). Plant water stress can be avoided by applying optimum irrigation water in the root zone. This requires an appropriate irrigation scheduling (Müller et al., 2016).

Irrigation scheduling of a crop is decision to take when to irrigate and how much quantity of water to be applied. Scheduling increases irrigation efficiency by reducing over land flow losses and percolation losses. In situations where water is not managed properly, resulted in increased energy and water use.

Irrigation scheduling can be done by two methods. One is soil water balance method, other one is soil and /or crop monitoring technique and soil water balance method uses estimation of evapotranspitaion, percolation, runoff and precipitation. Soil monitoring methods uses tensiometers and sensors at several locations in a field to measure soil water content or soil matric potential. Optimal irrigation scheduling using soil moisture tensiometers and sensors requires accurate threshold values for individual crops in the given agricultural systems. Soil matric potential thresholds values has shown a promising potential for saving water and improving yields (Müller et al., 2016). Threshold values are lower limit values which shows the degree to which soil can dry before irrigation is required. Generally threshold values are selected such that crops should not suffer water stress or no reduction in yield. Threshold soil matric potential values recommended in the literatures, conducted by various studies, found by researchers can be used to prepare irrigation scheduling. Soil matric potential based irrigation water application has been used to increase the yields of many agricultural crops (Pelletier et al., 2013; Shock and Wang, 2011).

The computation of crop evapotranspiration (ETc) is important for determining the soil water management and planning, at the same time increase water use efficiency and yield of the crop (Allen et al., 2011). To estimate the crop water requirement crop coefficient (Kc) based irrigation is most commonly used method. Kc value represents crop specific water use and is the required for accurate estimation of irrigation requirements of crops grown under different climatic conditions. The crop coefficient $(\mathrm{Kc})$ considers the crop type and crop development to adjust the reference evapotranspiration for that specific crop. Reference evapotranspiration can be calculated based on standard meteorological data. Allen et al., (2011) has presented standard tables for Kc values under different crop growth stages. Crop evapotranspiration for a particular crop can be calculated by multiplying reference evapotranspiration with crop coefficient of that crop under different growing stages. Irrigation can be decided based on crop evapotranspiration. Kc values suggested by FAO paper can be adjusted to local conditions by following local climatological parameters. Kc values can also be determined by computing actual crop water requirement using field water balance 
method. This method provides actual water use by crop, so accurate $\mathrm{Kc}$ values can be found. The $\mathrm{K}_{\mathrm{c}} \mathrm{ET}_{\text {ref }}$ approach provides a simple, convenient and reproducible way to estimate ET from a variety of crops and climatic conditions (Doorenbos and Pruitt, 1977). Accurate estimation of crop water requirement for water balance method can be done by adopting soil matric potential threshold values. It decides when to irrigate and how much to irrigate. Very limited research work has been carried out in the field of irrigation scheduling i.e., timing and amounts of water application over the growing season using soil matric potential threshold values. The objectives of this study are to determine the crop coefficient value for brinjal and irrigation interval at different growth stages.

\section{Materials and Methods}

\section{Experimental field}

Field Experiments were conducted during the two crop growing seasons from 13 November 2018 to 22 March 2019 and 13 April 2019 to 20 August 2019 at Central Farm (C-block) of Agricultural Engineering College and Research Institute, Kumulur, Tamil Nadu (India). The farm is at $10^{\circ} 92^{\prime}$ North Latitude and $78^{\circ} 82^{\prime}$ East Longitude at an elevation of $62 \mathrm{~m}$ above the Mean Sea Level. The average annual precipitation during the experimental is about $881.4 \mathrm{~mm}$. It has semiarid temperate climate, the average maximum temperature ranges from 32.4 to $35.2{ }^{\circ} \mathrm{C}$ and minimum temperature ranges from 15.8 to $22.5{ }^{\circ} \mathrm{C}$ during the experimental period. The average relative humidity during the study period was 65 to 71 per cent.

The textural class of experimental field is Sandy loam and the textural composition of Sand, Silt and Clay was 73.43, 14.23 and 12.34 per cent respectively. Other physical characteristics of soil viz. Bulk Density of 1.413 g/cc, Field capacity 22.26 per cent, Permanent wilting point 9.52 per cent), Infiltration rate $1.71 \mathrm{~cm} / \mathrm{h}$ and Saturated Hydraulic Conductivity of $41.1 \mathrm{~cm} /$ day are measured in the experimental soil.

\section{Layout of the experimental field}

The experiment was conducted in an area of $23 \mathrm{~m} \times 13 \mathrm{~m}$. The layout of the drip system consisted of ground level tank used to store the water and water was pumped using $1 \mathrm{HP}$ motor and conveyed to the $63 \mathrm{~mm}$ PVC main line pipes after filtering through sand filter. In the Head control unit, ventury was installed for fertigation. From the main pipe, $40 \mathrm{~mm}$ PVC sub mains pipes, from the sub main, 12 mm LDPE inline laterals having emitter spacing of $45 \mathrm{~cm}$ were drawn. Laterals were laid at the spacing of $90 \mathrm{~cm}$. The wetting diameter of dripper is $45 \mathrm{~cm}$ with discharge rate of $4 \mathrm{lph}$. Sub mains and laterals were closed at the end with end using caps.

The experimental field was ploughed twice using cultivator. Rotavator was used to break the clods and level the field. Before ploughing required organic manures were applied. The experimental field bed was formed manually with the spacing of $60 \mathrm{~cm}$. Drip irrigation laterals were laid at the centre of the bed.

In the experimental field 30 to 40 days old, healthy, well developed, almost uniform free from insect, pest and diseases were planted. Transplanting of Brinjal seedling was done on 13-11-2018 evening hours. Spacing between row-to-row and plant-to-plant were $90 \mathrm{~cm}$ and $45 \mathrm{~cm}$ respectively. Seedlings were transplanted near the emitter of the inline laterals. Irrigation was given immediately after transplanting for better growth of the plants in the experimental field. Similarly, for second growing season, field preparation work and planting of seeding was carried out. 
Brinjal (Solanum melongena L.) hybrid Dhruva F1 was planted manually in the experimental field, with row-row and plantplant spacing of $90 \mathrm{~cm}$ and $45 \mathrm{~cm}$ respectively. The cropping period of brinjal was 130 days and the crop duration was between 13 November 2018 to 22 March 2019. In the experimental field basal dose of Farm Yard Manure (FYM) was applied at the rate of $25 \mathrm{t} \mathrm{ha}^{-1}$.Fertigation was through the ventury. The recommended dose of NPK @ 200:150:100 $\mathrm{kg} \mathrm{ha}^{-1}$.

Four growth stages were considered (Allen et al., 1998): the initial stage (seedling establishment: 0-30 days), from transplanting to $10 \%$ canopy coverage; the development stage (vegetative: $31-70$ days), from then to effective full cover-age; the mid-season stage (flowering \& fruit formation: 71-110 days), from full coverage to start of maturity; and the late season, from then up to harvest (fruit harvesting: 111-130 days).

\section{Calibration of tensiometer}

The pressure difference between pore air and pore water is called a soil suction. Tensiometer provides a direct measure of the water tension held by soil, a measure of the soil moisture content indirectly. A tensoimeter was installed at the depth of 40 $\mathrm{cm}$ and soil sample were taken using auger at different tensiometer readings.

The soil moisture content was determined by gravimetric method. The known quantity of soil was dried in an electric oven at $105^{\circ} \mathrm{C}$ for 24 hours. A soil moisture characteristics graph with observed tensiometer reading on horizontal axis and soil moisture content on vertical axis was drawn for calibration.

Based on this calibration graph (Fig. 1), irrigation amounts can be decided when the tensiometer indicates that the matric suction had reached known prescribed values for the respective crop.

The following relationship was obtained:

$\mathrm{y}=0.0033 \mathrm{x}^{2}-0.6004 \mathrm{x}+26.013\left(\mathrm{R}^{2}=0.996\right)$

------ (1)

where $\mathrm{y}$ is $\operatorname{SMP}(\mathrm{kPa})$ and $\mathrm{x}$ is soil moisture content (\%).

\section{Depth of water applied}

The irrigation depths were then determined from:

$\mathrm{I}=\mathrm{A} \mathrm{Zt}(0.95 \mathrm{FC}-\mathrm{obs})$------ (2)

where I is the irrigation amount to be applied $\left(\mathrm{m}^{3}\right)$; A is the bed surface area of the plot $\left(\mathrm{m}^{2}\right) ; \mathrm{Zt}$ is the target root depth $(\mathrm{m})$; FC is the soil water content at field capacity $\left(\mathrm{m}^{3} / \mathrm{m}^{-3}\right)$; obs is the soil water content $\left(\mathrm{m}^{3} / \mathrm{m}^{-3}\right)$ corresponding to the SMP observed before irrigation. Given the adoption of frequent irrigations and previous field observations of the root distribution, $\mathrm{Zt}$ was set at $0.30 \mathrm{~m}$, which is smaller than the effective root depth $\mathrm{Zr}=0.60 \mathrm{~m}$.

\section{Installation of tensiometer}

Tensoimeter were installed based on maximum rooting depth of the brinjal crop. The brinjal growing periods were divided into the initial stage, development stage, midseason stage and end stages. Four growth stages of brinjal are initial stage, crop development stage, mid-season stage and end stage. The initial stage was from transplanting to plant growing period. The development stage was from growing period to the flowering phase and the middle period was selected from the flowering phase to yielding phase, whereas the final stage was selected from yielding up to the harvesting period. In 
order to assess the root growth developed in each stage, the maximum root zone depth penetrated in the soil and maximum rooting intensity was measured. The rooting depth was measured manually by excavating the soil at the root zone and measures the maximum rooting depth in each stage. At initial stage maximum root zone depth was measured in twenty days after transplanting (DAT) because initially root development was less. The maximum root zone depth measured in the initial stage was $10 \mathrm{~cm}$. Similar result was found by Dabach et al., (2015). In the same way for crop development stage, midseason and late season stage maximum root zone depth was measured at 35 DAT, 75 DAT and 115 DAT. The root zone depths measured for 35 DAT, 75 DAT and 115 DAT were 15 $\mathrm{cm}, 20 \mathrm{~cm}$ and $22 \mathrm{~cm}$ respectively. The maximum rooting intensity was measured at $10 \mathrm{~cm}$ depth for all four stages. Based on the measured maximum root zone depth, tensoimeters were installed in the soil. Two tensoimeters were installed for each stage of growing season. One tensoimeter was installed at the maximum root zone depth and another one was installed at the maximum rooting intensity of the crop. Depth of installation of tensiometer at different growth stages is given in Table 1.

\section{Determination of Irrigation Interval}

Proper irrigation scheduling is very much essential for the effective use of required water by the crop in the micro irrigation system. It also improves the crop yield, quality and water use and reduce production cost. In the experimental field irrigation scheduling was done based on continuous recording of tensiometer readings. After transplanting of brinjal seedling, common irrigation was given for twenty days at regular interval. After twenty days tensiometers were installed at maximum rooting depth and maximum rooting intensity of two healthy well grown brinjal crops. Tensoimeters were placed throughout the crop period for different depth. Brinjal crop was irrigated based on daily reference crop evapotranspiration $\left(\mathrm{ET}_{0}\right)$. After the irrigation tensiometer readings were noted three times in a day (Liu et al., 2012), it was 8 am, 2 pm and $5 \mathrm{pm}$. The next irrigation was given when the soil matric potential reached 15 to $20 \mathrm{kPa}$. Various studies indicated that irrigation to crop under sandy loam soil for solanaceae family crops was based on soil matric potential value of 15 to $20 \mathrm{kPa}$ (Marouelli and Silva, 2007) Smajstrla and Locascio, 1996 and Liu et al., 2012). The soil matric potential observed by tensiometers was used to determine the irrigation interval of brinjal crop.

\section{Estimation of reference evapotranspiration $\left(\mathrm{ET}_{\mathbf{0}}\right)$}

The $\mathrm{ET}_{0}$ was estimated by Penman-Monteith (Allen et al., 1998) equation using 25 years meteorological data collected from meteorological observatory located in AEC \& RI, Kumulur. $\mathrm{ET}_{0}$ was calculated by the method described in FAO Paper 56 by using the program FAO $\mathrm{ET}_{0}$ Calculator (Raes, 2009). For the study purpose 25 years average $\mathrm{ET}_{0}$ was taken from the $\mathrm{ET}_{0}$ value estimated for all 25 years. Penman-Monteith equation for reference ET as followed by,

$E T_{0}=\frac{0.403 \Delta\left(R_{n}-G\right)+\gamma \frac{900}{T+273} u_{2}\left(e_{s}-e_{a}\right)}{\Delta+\gamma\left(1+0.34 u_{2}\right)}$

Where,

$\mathrm{ET}_{0}=$ Reference evapotranspiration $(\mathrm{mm} /$ day $), \mathrm{Rn}=\mathrm{Net}$ radiation at the crop surface $\left(\mathrm{MJm}^{-2} /\right.$ day $), \mathrm{G}=$ Soil heat flux density $\left(\mathrm{MJm}^{-2} /\right.$ day $), \mathrm{T}=\quad$ Mean daily air temperature at $2 \mathrm{~m}$ height $\left({ }^{\circ} \mathrm{C}\right), \mathrm{u}_{2}=$ wind speed at $2 \mathrm{~m}$ height $(\mathrm{m} / \mathrm{s}), \mathrm{e}_{\mathrm{s}}=$ Saturation vapour pressure $(\mathrm{kPa}), \mathrm{e}_{\mathrm{a}}=$ Actual vapour 
pressure $(\mathrm{kPa}), \mathrm{e}_{\mathrm{s}}-\mathrm{e}_{\mathrm{a}}=$ Saturation vapour pressure deficit $(\mathrm{kPa}), \Delta=$ Slope vapour pressure curve $\left(\mathrm{kPa}^{0} / \mathrm{C}\right), \gamma=$ Psychrometric constant $\left(\mathrm{kPa}^{0} / \mathrm{C}\right)$

\section{Estimation of crop coefficient $\left(K_{c}\right)$ for brinjal}

The daily crop water requirement (CWR) for brinjal crop was estimated using reference crop evapotranspiration, crop coefficient and plant canopy factor and its calculated by using the following formula,

CWR $=$ Reference evapotranspiration $\mathrm{x}$ Crop coefficient $x$ Canopy factor

Crop coefficient $\left(\mathrm{K}_{\mathrm{c}}\right)$ is the ratio of reference evapotranspiration $\left(E T_{0}\right)$ and crop evapotranspiration $\left(E T_{C}\right)$ as followed by equation

$K_{C}=\frac{E T_{0}}{E T_{C}}$

Crop coefficient for brinjal at different growth stages given in FAO 56 paper (Allen et al., 1998) was used for calculating the crop evapotranspiration $\left(E T_{C}\right)$. The crop coefficient value of the brinjal crop was 0.6 , $0.825,1.05$ and 0.9 during initial stage, development stage, mid stage and end stage.

\section{Estimation of actual crop evapotranspiration $\left(\mathrm{ET}_{\mathrm{c}}\right)$ by soil water balance method}

The crop evapotranspiration $\left(\mathrm{ET}_{\mathrm{c}}\right)$ of the brinjal was estimated using a soil water balance method (Liu et al., 2012) as

$E T_{C}=I+P \pm \Delta S+C R-D-R$

Where,

$\mathrm{ET}_{\mathrm{C}}$ is the Actual crop evapotranspiration $(\mathrm{mm} /$ day), $\mathrm{I}$ is the Irrigation depth $(\mathrm{mm}), \mathrm{P}$ is the Precipitation $(\mathrm{mm}), \Delta \mathrm{S}$ is the Change in soil water storage from the maximum root zone depth, CR is the Capillary rice ( $\mathrm{mm}), \mathrm{D}$ is the Deep percolation ( $\mathrm{mm}), \mathrm{R}$ is the Surface runoff $(\mathrm{mm})$

Tensiometer data is used to determine the change in soil moisture in maximum root zone depth at different growing stages. Soil moisture characteristics curve was used to determine the moisture content value at different tensiometer readings. During the study period one or two low precipitation was occur, so that it is negligible. Surface runoff was ignored because no runoff was observed during the study period. Below the root zone depth deep percolation was neglected because depth of irrigation water applied was small and water applied to compensate the soil moisture deficit in the root zone caused by crop evapotranspiration. In addition rainfall during the growing season was very small and unable to create deep percolation, hence deep percolation was also neglected.

\section{Results and Discussion}

\section{Determination of Irrigation Interval}

Proper irrigation water management requires knowledge of irrigation scheduling. Irrigation scheduling of crop gives the details about when to irrigate and how much to irrigate. Irrigation scheduling based on soil matric potential measured using tensiometers provides accurate results on time of irrigation. So the time of irrigation was decided based on soil matric potential observed using tensiometer installed at a depth of maximum rooting intensity of crop. Irrigation was given to brinjal crop when soil moisture reaches before wilting point. Irrigation was given when the soil matric potential exceeds 15 to $20 \mathrm{kPa}$. The soil matric potential was noted at three times in a day at $8 \mathrm{am}, 2 \mathrm{pm}$ and $5 \mathrm{pm}$. The soil matric potential has an inverse 
relation with the soil water content. Higher soil matric potential indicates lesser soil water content. The soil matric potential observed at a depth of $10 \mathrm{~cm}$ is shown in Fig.2 to 5. Each crop growth stage of brinjal irrigation interval was determined based on the continuous measurement of tensiometer readings.

Fig. 2 to 5 presents the irrigation interval by comparing soil matric potential vs time for different crop growing stages for I crop (Nov 18 - Mar 19). It was found that interval between two successive irrigation was less, hence higher number of irrigation was observed. No of irrigation based on the continuous measurement of tensiometer readings is shown in Table 2. At the initial stage number of irrigation was 9, for development stage, mid-season stage and end stage of the crop, the number of irrigation was 14,15 and 6 times respectively and the total number of irrigation was 44. Irrigation interval based on soil matric potential threshold values ranges from 1 to 2 days in drip irrigation. Similar pattern of number of Irrigation was observed for II crop (Apr 19 Aug 19) also.

Table.1 Tensiometer installation depth at different growth stage

\begin{tabular}{|l|c|c|}
\hline \multicolumn{1}{|c|}{ Growth stage } & $\begin{array}{c}\text { Maximum Rooting } \\
\text { intensity(cm) }\end{array}$ & $\begin{array}{c}\text { Maximum Rooting depth } \\
(\mathbf{c m})\end{array}$ \\
\hline Initial stage & 10 & 10 \\
\hline Development stage & 10 & 15 \\
\hline Mid-season & 10 & 20 \\
\hline Late season & 10 & 22 \\
\hline
\end{tabular}

Table.2 Number of irrigation in two crop period for brinjal

\begin{tabular}{|l|c|c|c|}
\hline \multicolumn{1}{|c|}{ Crop growth stage } & Duration, days & $\begin{array}{c}\text { I crop } \\
\text { (Nov 18 - Mar 19) days }\end{array}$ & $\begin{array}{c}\text { II crop } \\
\text { (Apr 19 - Aug 19) days }\end{array}$ \\
\hline Initial stage & 30 & 9 & 10 \\
\hline Development stage & 40 & 14 & 12 \\
\hline Mid-season stage & 40 & 15 & 15 \\
\hline End stage & 20 & 6 & 7 \\
\hline Total & $\mathbf{1 3 0}$ & $\mathbf{4 4}$ & $\mathbf{4 4}$ \\
\hline
\end{tabular}

Table.3 Crop Evapotranspiration and Crop coefficient value of Brinjal for different growing stages

\begin{tabular}{|c|c|c|c|c|c|c|c|c|c|}
\hline \multirow[t]{2}{*}{ S.No } & \multirow[t]{2}{*}{ Crop growth stage } & \multirow[t]{2}{*}{ Days } & \multirow[t]{2}{*}{ FAO K $_{\mathrm{C}}$} & \multicolumn{3}{|c|}{$\begin{array}{c}\text { I crop } \\
(\text { Nov } 18-\text { Mar 19) }\end{array}$} & \multicolumn{3}{|c|}{$\begin{array}{c}\text { II crop } \\
\text { (Apr 19 - Aug 19) }\end{array}$} \\
\hline & & & & $\underset{(\mathbf{m m})}{\mathbf{E T}_{\mathbf{C}}}$ & $\begin{array}{l}\mathbf{E T}_{\mathbf{0}} \\
(\mathbf{m m})\end{array}$ & $\begin{array}{c}\text { Estimated } \\
\mathbf{K}_{\mathbf{C}}\end{array}$ & $\begin{array}{c}\mathbf{E T}_{\mathbf{C}} \\
(\mathbf{m m})\end{array}$ & $\begin{array}{l}\mathbf{E T}_{0} \\
(\mathbf{m m})\end{array}$ & $\begin{array}{c}\text { Estimated } \\
\mathbf{K}_{\mathbf{C}}\end{array}$ \\
\hline 1 & Initial stage & 30 & 0.60 & 60 & 105.2 & 0.57 & 85 & 143.9 & 0.59 \\
\hline 2 & Development stage & 40 & 0.825 & 121 & 144.2 & 0.83 & 162 & 193.8 & 0.84 \\
\hline 3 & Mid-season stage & 40 & 1.05 & 184 & 178.1 & 1.03 & 189 & 185.4 & 1.02 \\
\hline 4 & End stage & 20 & 0.90 & 98 & 117.1 & 0.84 & 79 & 96.6 & 0.82 \\
\hline & Total & & & 463 & & & 515 & & \\
\hline
\end{tabular}


Fig.1 Soil moisture characteristics curve

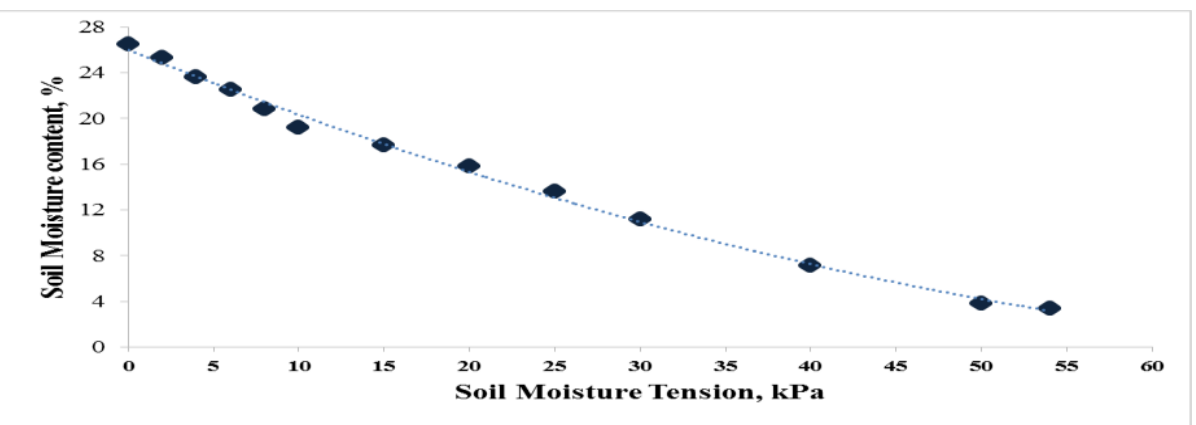

Fig.2 Irrigation interval for initial stage (0 - 30 days)

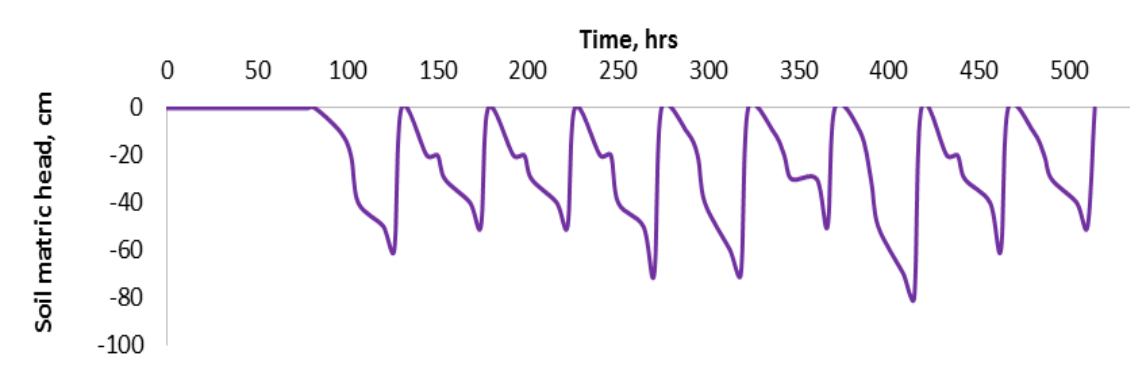

Fig.3 Irrigation interval for crop development stage (31- 70 days)

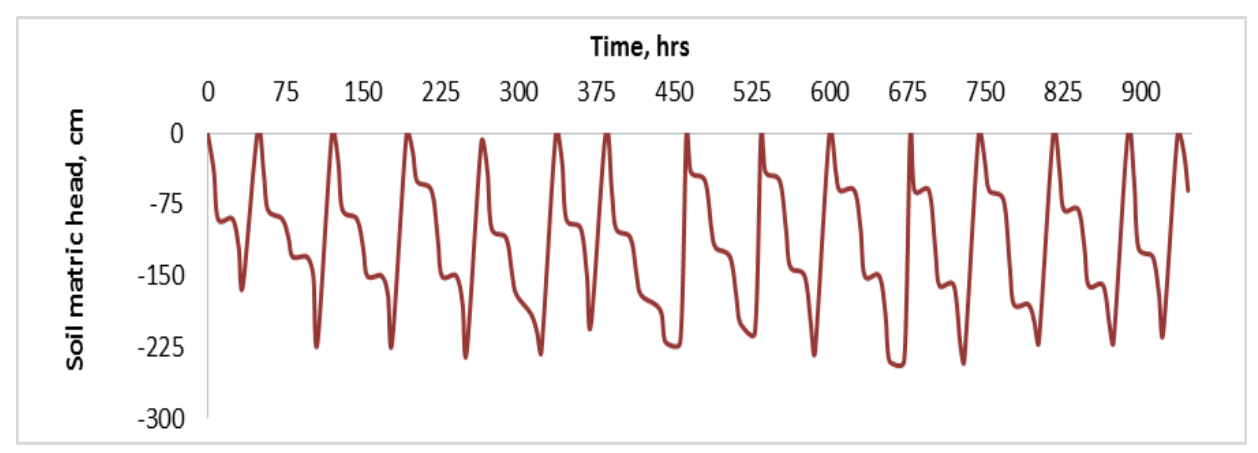

Fig.4 Irrigation interval for mid-season stage (71 - 110 days)

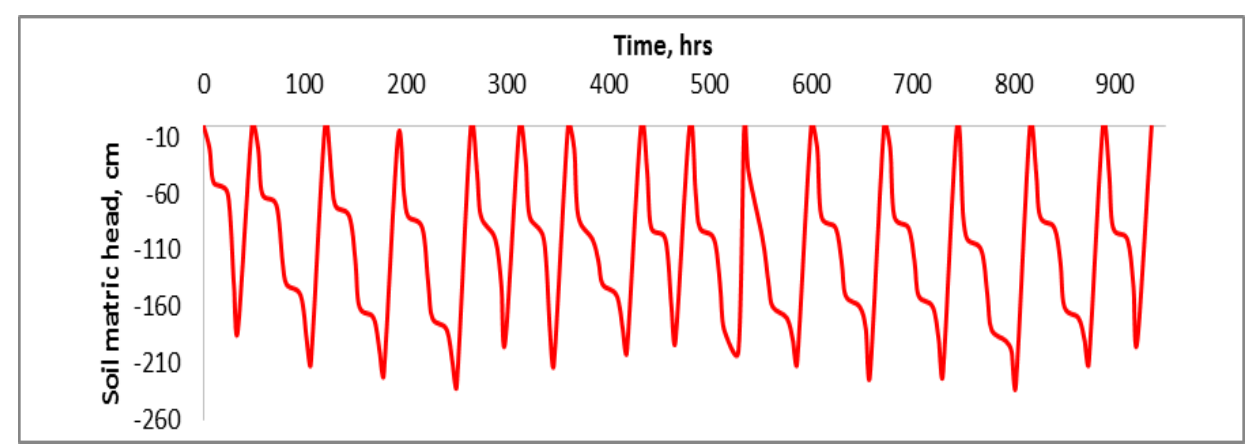


Fig.5 Irrigation interval for late season stage (111 - 130 days)

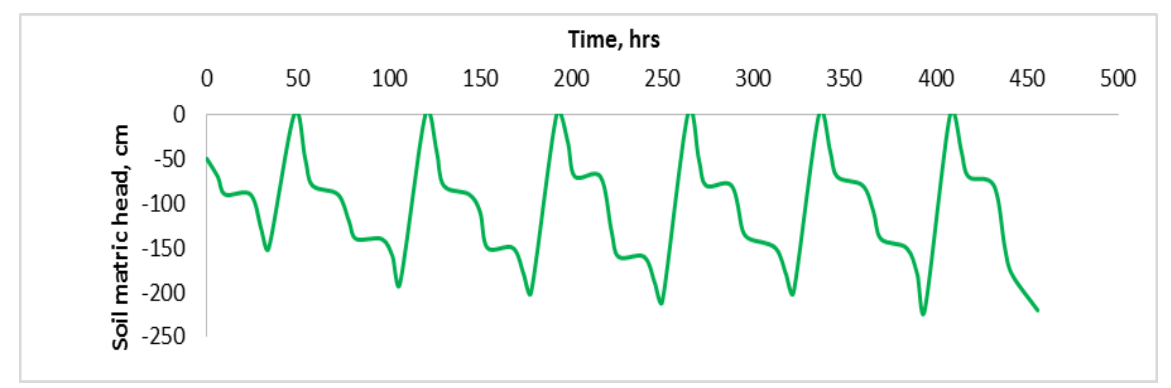

Fig.6 Daily Crop Evapotranspiration and Crop coefficient values of Brinjal for I and II crop
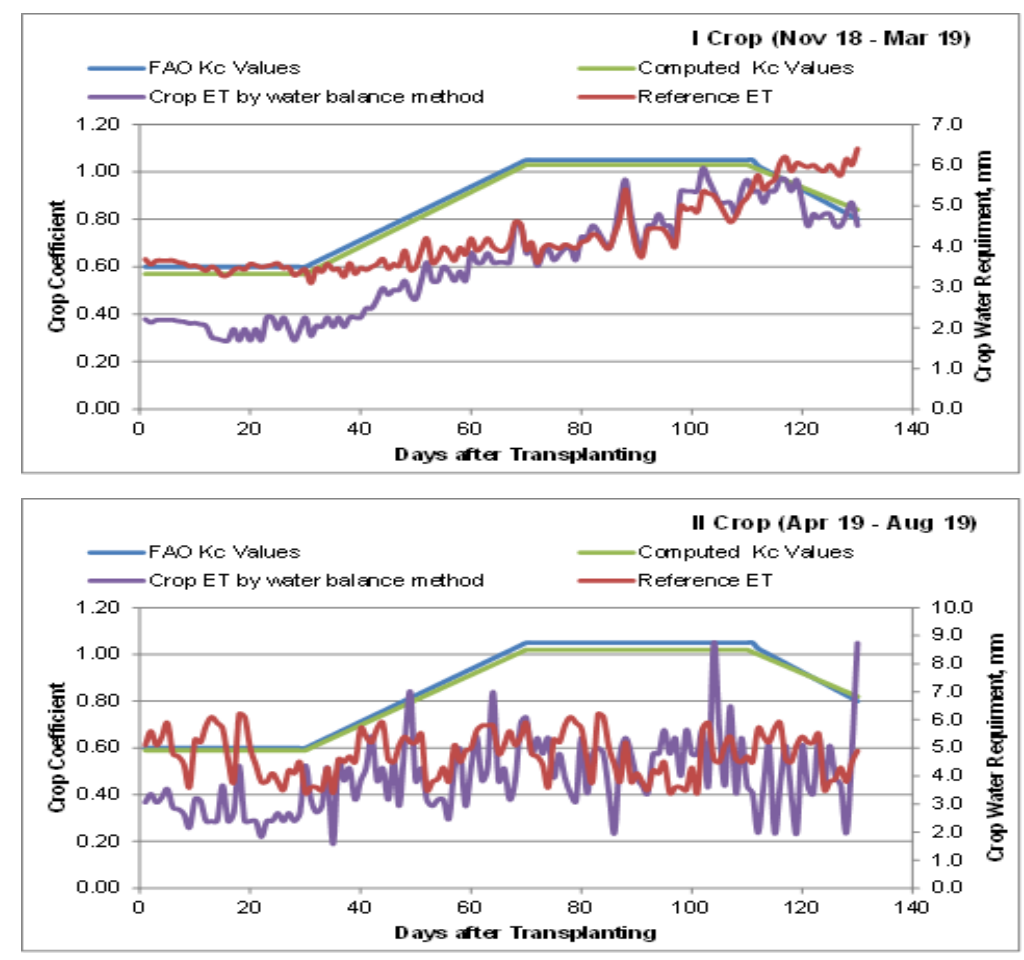

Computation of crop water requirement for brinjal

\section{Estimation of reference crop evapotranspiration $\left(\mathbf{E T}_{\mathbf{0}}\right)$}

Reference crop evapotranspiration was calculated for the two crop growing season using ETo calculator. The ETo calculator calculated the reference evapotranspiration from the 25 years meteorological date and the 25 years average reference evapotranspiration were taken for this purpose. Minimum temperature, maximum temperature, wet and dry bulb temperature, relative humidity and wind speed and other local climatic condition were used for determining reference crop evapotranspiration.

Estimation of actual crop evapotranspiration (ETc) by soil water balance method

Soil water balance method was used to determine the actual crop evapotranspiration by considering the change of soil water content present in the soil computed by change in soil water tension. It was also considered to neglect the runoff and deep percolation. 
The actual crop evapotranspiration (ETc) estimated by water balance method for brinjal gradually increased from initial stage to development stage and to end stage of the crop.

\section{Estimation of crop coefficient $\left(K_{c}\right)$ for brinjal}

The crop coefficient values were estimated on a daily basis from the initial stage to the end stage of the cropping period from actual ETc and ETo. The Kc value for four different growth stages of Brinjal for two crop seasons are graphically depicted in the Figure 6.

Crop Evapotranspiration and Crop coefficient value of Brinjal for different growing stages is presented in Table 3. Total crop water requirement of brinjal for a crop period of Nov 18 - Mar 19 was measured as $463 \mathrm{~mm}$ and for crop period of Apr 19 - Aug 19 as 515 mm. Irrigation water applied was higher for II crop when compared to the I crop, it might be calculated ETo values were higher in the II crop. The crop coefficient $(\mathrm{Kc})$ value increases from development stage and it remained at high level during mid stage. At the late stage, the $\mathrm{Kc}$ value declined. Carvalho et al, 2012 reported that the crop coefficient values of eggplant for different crop stages viz, TransplantingFlowering, Flowering - Fructification, Fructification - First harvest and First harvest End of cycle estimated by using a weighing lysimeter was $0.81,1.14,1.17$ and 1.05 respectively.

Marouelli et al., (2001) estimated the values of $\mathrm{kc}$ for the eggplant for different sub periods and found that at initial period, the $\mathrm{kc}$ was 0.95 , decreasing at vegetative stage to 0.85 and reaching a higher value at fructification is 1.15 , with a subsequent decrease $(0.85)$ in the end period.

Estimated crop coefficient values of Brinjal were compared with FAO guideline Kc values. From the table it can be seen that the estimated crop coefficients were matching nearly with the FAO guideline Kc values.
In fact, the FAO guideline $\mathrm{Kc}$ values represent the average data from various environmental conditions and cultivars, while the Kc values arrived in this study refer to the local environmental conditions. In summary the development of local crop coefficient helps tremendously in irrigation management and furthermore provides precise water applications in water scarce areas.

In conclusion the Field experiment was conducted to estimate crop coefficient at different crop growing stages and irrigation interval for brinjal based on soil matric potential. Tensiometers were used to observe soil matric potential at different crop growing stages. Depth of installation of tensiometer was decided based on maximum rooting depth and maximum rooting intensity. Irrigation was given to brinjal crop when the soil matric potential reached at 15 to $20 \mathrm{kPa}$. Amount of irrigation water applied to the crop was decided based on crop evapotranspiration. Actual crop water requirement was calculated by water balance method. Irrigation interval was decided based on soil matric potential threshold values, it was found as 1 to 2 days (44 irrigation). Crop coefficient value of brinjal was calculated by taking ratio of actual crop ET and reference crop ET. Computed Kc values at initial, development, mid and end stage of the brinjal for I crop period was $0.57,0.83,1.03,0.84$ and for II crop period was $0.59,0.84,1.02,0.82$. Field test verification of crop water requirement for drip irrigated brinjal by soil water balance method shows that Food \& Agricultural Organization (FAO) method can be used by farmers to irrigate the crops.

\section{References}

Allen, Richard G., Luis S. Pereira, Dirk Raes, and Martin Smith. 1998. Crop evapotranspiration - Guidelines for computing crop water requirements. FAO Irrigation and drainage paper 56.

Allen, Richard G., Luis S. Pereira, Terry A. Howell, and Marvin E. Jensen. 2011. 
Evapotranspiration information reporting: I. Factors governing measurement accuracy. Agricultural Water

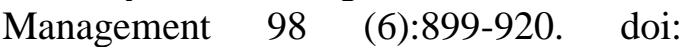
10.1016/j.agwat.2010.12.015.

Carvalho, D. F. De., Marcio E. De Lima, Alexsandra D. De Oliveira, Hermes S. Da Rocha, José G. M. Guerra. (2012). Crop coefficient and water consumption of eggplant in no-tillage system and conventional soil preparation. Eng. Agríc., Jaboticabal, v.32, n.4, p.784-793.

Dabach, Sharon, Uri Shani, and Naftali Lazarovitch. 2015. Optimal tensiometer placement for high-frequency subsurface drip irrigation management in heterogeneous soils. Agricultural Water Management 152:91-98. doi: 10.1016/j.agwat.2015.01.003.

Datta, Sumon, Saleh Taghvaeian, and Jacob Stivers. 2017. Understanding Soil Water Content and Thresholds for Irrigation Management. Division of Agricultural Sciences and Natural Resources 6.

Doorenbos J, Pruitt WO. 1977. Crop water requirements. Irrigation and Drainage Paper No. 24 (rev.) FAO, Rome, 144 p

Horticultural Statistics at a Glance. 2017. Horticulture Statistics Division, Department of Agriculture, Cooperation \& Farmers Welfare, Ministry of Agriculture \& Farmers Welfare, Government of India

Li,Q.Z., Hao,W.P., Gong, D.Z., 2007. Effect of different irrigation pattern on soil water dynamics, water use and yields in Apple Orchard. Agricultural Research in the
Arid Areas. 25 (2), 128-132.

Liu, Haijun, Huiying Yang, Jianhua Zheng, Dongdong Jia, Jun Wang, Yan Li, and Guanhua Huang. 2012. Irrigation scheduling strategies based on soil matric potential on yield and fruit quality of mulched-drip irrigated chili pepper in Northwest China. Agricultural Water Management 115:232-241. doi: 10.1016/j.agwat.2012.09.009.

Marouelli, Waldir A., Silva, and Washington L. C. 2007. Water tension thresholds for processing tomatoes under drip irrigation in Central Brazil. Irrigation Science 25 (4):411-418. doi: 10.1007/s00271-0060056-6.

Müller, T., C. Ranquet Bouleau, and P. Perona. 2016. Optimizing drip irrigation for eggplant crops in semi-arid zones using evolving thresholds. Agricultural Water Management 177:54-65. doi: 10.1016/j.agwat.2016.06.019.

Pelletier, V., Gallichand, J., Caron, J., 2013. Effect of soil water potential threshold for irrigation on cranberry yield and water productivity. Trans. Am. Soc. Agric.Biol. Eng. 56, 1325-1332, http://dx.doi.org/10.13031/trans.56.10374

Raes, Dirk. 2009. The ETo Calculator. Food and Agriculture Organization of the United Nations Land and Water Division $3(9)$.

Shock, C.C., Wang, F.X., 2011. Soil water tension, a powerful measurement for productivity and stewardship. HortScience 46, 178-185.

\section{How to cite this article:}

Manikandan, M. and Ravikumar, V. 2020. Soil Matric Potential Based Irrigation Schedule for Brinjal. Int.J.Curr.Microbiol.App.Sci. 9(08): 3602-3612. doi: https://doi.org/10.20546/ijcmas.2020.908.415 